\title{
Endocannabinoid system and pregnancy
}

\author{
Fernando Correa, Manuel L Wolfson, Paula Valchi, Julieta Aisemberg and Ana María Franchi \\ Center for Pharmacological and Botanical Studies, National Research Council, School of Medicine, \\ University of Buenos Aires, Buenos Aires, Argentina
}

Correspondence should be addressed to A M Franchi; Email: anafranchi2000@gmail.com

\begin{abstract}
The endocannabinoid system (eCS), is a complex system, comprising the main endogenous ligands anandamide and 2-arachidonoyl glycerol, the cannabinoid receptors CB1 and CB2 and the biosynthetic and degrading enzymes. Cumulative evidence shows that the eCS plays an important role in reproduction, from egg fertilization to parturition. Therefore, alterations in this system, either by recreation/therapeutic use of cannabis or deregulation of the endogenous cannabinoids, might lead to adverse pregnancy outcomes, including retardation in embryo development, poor blastocyst implantation, inhibition of decidualization, miscarriage and compromised placentation. Nevertheless, the molecular mechanisms by which the eCS participates in different stages of pregnancy remain poorly understood. In this review, we will examine the evidence from animal and human studies to support the role of the eCS in implantation, early-to-late pregnancy and placentation as well as the difficulties of targeting this system for treatment of female infertility.

Reproduction (2016) 152 R191-R200
\end{abstract}

\section{The endocannabinoid system}

Humans have been consuming cannabis since prehistory, not only for religious/spiritual or hedonic purposes but also for its purported medicinal effects. However, for a long time, research on active principles of cannabis remained elusive. It was not until the mid-1960s that Mechoulam and Gaoni (1965) isolated and characterized the main psychoactive component of Cannabis sativa, $\Delta^{9}$-tetrahydrocannabinol (THC). Due to its lipophilic nature, it was first believed that THC exerted its psychoactive effects by nonspecific mechanisms. However, in the late 1980s, Devane and coworkers (1988) identified a specific binding site for cannabinoids in the rat brain; a couple of years later, Matsuda and coworkers (1990) cloned the first cannabinoid receptor, which is now known as type 1 cannabinoid receptor (Cb1). Shortly after this discovery, a second cannabinoid receptor was identified by sequence homology and was named as type 2 cannabinoid receptor (Cb2) (Munro et al. 1993). Initially, it was presumed that CB1 was expressed mainly in the central nervous system (CNS) and CB2 in the periphery. However, today it is well established that both receptors are expressed in the CNS and peripheral tissues. CB1 and CB2 belong to the superfamily of 7-transmembrane $\mathrm{G}$ protein-coupled receptors (GPCRs). Activation of both receptors results in the inhibition of cyclic AMP (Matsuda et al. 1990, Slipetz et al. 1995), activation of mitogen-activated protein kinase (MAPKs) signaling pathways (Bouaboula et al.
1995, 1999, Sánchez et al. 1998, Wang et al. 2003, Correa et al. 2005, 2009, Franklin \& Carrasco 2013), regulation of $\mathrm{Ca}^{2+}$ channels and inwardly rectifying $\mathrm{K}^{+}$currents (Caulfield \& Brown 1992, Mackie \& Hille 1992, Gebremedhin et al. 1999, Begg et al. 2003, Wang et al. 2003) and activation of phospholipase C (Zoratti et al. 2003). Cumulative evidence suggests the existence of a putative third type of cannabinoid receptor ('CB3'), called GPR55 (Ryberg et al. 2007, Sharir \& Abood 2010). Interestingly, and adding complexity to the pharmacology of cannabinoids, it has been shown that these compounds might elicit response in other receptors, such as transient receptor potential vanilloid 1 (TRPV1), peroxisome proliferatoractivated receptors (PPARs) and GPR119 (Huang et al. 2002, Sun et al. 2006, Syed et al. 2012).

The first endogenous ligand for cannabinoid receptors, arachidonylethanolamide (AEA), was isolated in 1992 by the efforts of Dr. Mechoulam's lab, and it was named 'anandamide' (Devane et al. 1992). Not long after that, a second endogenous ligand, 2-arachidonoyl glycerol (2-AG), was discovered (Mechoulam et al. 1995, Sugiura et al. 1995). AEA and 2-AG are the best characterized and most studied endogenous cannabinoids or 'endocannabinoids'. Nonetheless, many other endocannabinoids have been identified, such as $\mathrm{O}$-arachidonoyl ethanolamine (virodhamine) (Porter 2002), 2-arachidonoyl glycerol ether (noladin ether) (Hanus et al. 2001) and $\mathrm{N}$-arachidonoyl-amino acids such as $\mathrm{N}$-arachidonoyl-dopamine (NADA) 
(Huang et al. 2002). However the physiological role of these and other naturally occurring endocannabinoids have not been extensively studied.

Endocannabinoids are not stored in vesicles but synthesized de novo upon demand via the hydrolysis of cell membrane lipid precursors (Fig. 1). The canonical biosynthetic pathway for AEA is the sequential action of $\mathrm{N}$-acyltransferase (NAT) and $\mathrm{N}$-acylphosphatidylethanolamine-specific phospholipase D (NAPE-PLD) (Di Marzo et al. 1994, Sugiura et al. 1996). For 2-AG, the main biosynthetic pathway involves the hydrolysis of phosphatidylinositol by phospholipase $\mathrm{C}$ (PLC), producing 1,2-diacylglycerol (DAG), which is then converted into 2 -AG by a diacylglycerol lipase $\alpha / \beta$ (DAGL) (Prescott \& Majerus 1983, Sugiura et al. 1995).

Once released, the endocannabinoids bind to CB1 and/or CB2 receptor to elicit their effect. Endocannabinoid-mediated signaling is terminated by their fast catabolism, mainly through the action of hydrolytic enzymes. AEA is rapidly degraded by the fatty acid amide hydrolase (FAAH) (Cravatt et al. 1996), whereas 2-AG is inactivated by the monoacylglycerol lipase (MAGL) (Dinh et al. 2002). However, alternative pathways have been described. Thus, AEA and 2-AG can be oxidized by the cyclooxygenase-2 (COX-2), distinct lipoxygenases (LOXs) or cytochrome P450 (CYP) into metabolic products, which produce biological effects by cannabinoid receptor-independent mechanisms (Yu et al. 1997, Burstein et al. 2000, Kozak et al. 2002, Urquhart et al. 2015). Again, there is a paucity of data on the pathophysiological role of these metabolic products and their mechanisms of action.

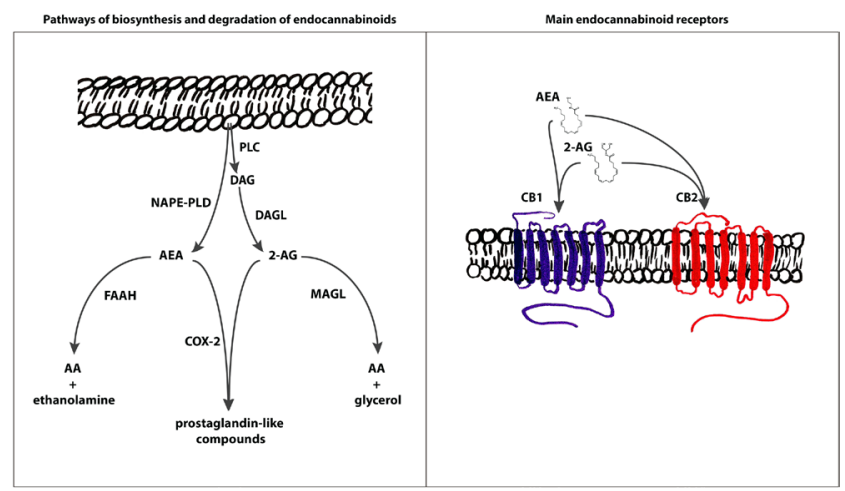

Figure 1 Schematic representation of components of the endocannabinoid system with the postulated pathways of biosynthesis and degradation of anandamide (AEA) and 2-arachidonylglycerol (2-AG), as well as their site of action. $\mathrm{AA}$, arachidonic acid; CB1, cannabinoid receptor type 1 ; CB2, cannabinoid receptor type 2; COX-2, cyclooxygenase type 2; DAG, diacylglycerol; DAGL, diacylglycerol lipase; FAAH, fatty acid amide hydrolase; MAGL, monoacylglycerol lipase; NAPE-PLD, $\mathrm{N}$-acylphosphatidylethanolamine-specific phospholipase D; PLC, phospholipase C.

\section{The endocannabinoid system in reproductive tissues}

Clinical observations have reported that heavy cannabis users present altered parameters associated with a diminished fertility capacity and reproductive failure, such as decreased plasma testosterone levels, reduced sperm count, alterations in sperm motility and capacitation, embryotoxicity and fetal abnormalities as well as early pregnancy termination (reviewed by Wang et al. 2006a). Moreover, a reduced success rate of in vitro fertilization is reported in cannabis consumers (Klonoff-Cohen et al. 2006). These observations prompted researchers to investigate the presence and function of components of the eCS in both male and female reproductive tissues. Thus, it has been shown that $\mathrm{N}$-acylethanolamines are present in rodent and human reproductive fluids (Schuel et al. 2002) and that the endometrium expresses higher levels of AEA than any other reproductive tissues (Das et al. 1995). Different lines of research have demonstrated the presence of the entire active eCS (NAPE-PLD, CB1, CB2 and FAAH) in rodent and in human ovarian tissue (El-Talatini et al. 2009a), oviduct (Wang et al. 2006b), uterus (Das et al. 1995, Paria et al. 2001, Scotchie et al. 2015) and testis (Cobellis et al. 2006, Battista et al. 2008). In male reproductive tissues, CB1 is expressed in germ cells, from spermatogonia to spermatozoa (Rossato et al. 2005), and Leydig cells (Gye et al. 2005), while CB2 is expressed in Sertoli cells (Maccarrone et al. 2003a). In female reproductive tissues, CB1 and CB2 receptors have been detected in oocytes at all stages of maturation, whereas NAPE-PLD and FAAH expressions are high in growing secondary and tertiary follicles and corpora lutea and albicantia (El-Talatini et al. 2009b). Furthermore, AEA levels in human follicular fluid correlates with oocyte maturation (El-Talatini et al. 2009a).

It is well established that plasma AEA levels fluctuate with the natural menstrual cycle, with the highest levels during the follicular phase (Lazzarin et al. 2004, El-Talatini et al. 2010). Interestingly, the expression and distribution of FAAH, NAPE-PLD, CB1 and CB2 in female reproductive tissues also vary with the menstrual cycle (reviewed in Di Blasio et al. 2013), suggesting that the eCS expression is under hormonal control. Indeed, progesterone and estrogen are shown to regulate the AEA levels by modulating the uterine expression of FAAH (Maccarrone et al. 2000a). Conversely, gonadotrophin secretion is regulated by endocannabinoids via activating CB1 receptors localized at the preoptic area of the hypothalamus (Park et al. 2004). At this level, cannabinoids negatively regulate the activity of gonadotrophin-releasing hormone $(\mathrm{GnRH})$-secreting neurons (Gammon et al. 2005). However, CB1 receptors are also present at the pituitary level, suggesting a localized effect of cannabinoids on luteinizing hormone (LH) and folliclestimulating hormone (FSH) (Wenger et al. 1995). 
A cannabinoid-induced downregulation of $\mathrm{GnRH}, \mathrm{LH}$ and/or FSH secretion might explain the reduced plasma testosterone levels and decreased sperm count found in heavy marijuana consumers (Whan et al. 2006).

Despite the amount of data available, the precise role of the eCS in male and female fertility remains poorly understood and conflicting data have been reported, suggesting the need for further research of the physiological role of the eCS in reproductive organs (reviewed by Karasu et al. 2011). Here, we will focus on the physiological and pathological roles of the eCS throughout pregnancy.

\section{The endocannabinoid system during implantation}

Implantation is the very early stage of pregnancy at which the blastocyst adheres and invades the wall of the uterus. The process of implantation implies a highly synchronized and complex bidirectional communication between the conceptus and the luminal endometrial cells, and it could be divided in three stages: apposition, adhesion and penetration. On contact with the blastocyst, the underlying area of contact in the stroma becomes increasingly vascularized and edematized. This process is called 'primary decidualization reaction'.

The endocannabinoid system plays an important role during the process of implantation. Studies in mice have shown that a delicate balance between anandamide (AEA) synthesis (driven mainly by NAPE-PLD) and degradation (mainly by FAAH) is necessary to ensure an appropriate 'AEA tone' during implantation (Paria et al. 1996, Guo et al. 2005). Indeed, it has been shown that too high and too low levels of AEA are deleterious for pregnancy (Sun \& Dey 2009). Accordingly, in vitro experiments have demonstrated that high levels of AEA inhibit the development of 2-cell embryos into blastocysts and the lysis of the zona pellucida (a process known as 'zona hatching') as well as the trophoblast differentiation (Schmid et al. 1997, Wang et al. 2006b). Conversely, in vitro low levels of AEA accelerate the trophoblast differentiation and outgrowth. Interestingly, CB2 is present as early as 1-cell stage through blastocyst stage, whereas Cb1 mRNA is only detected from 4-cell stage onward (Paria et al. 1995).

On the maternal side, AEA and 2-AG are produced by the murine uterus, and their levels are tightly regulated by the NAPE-PLD/FAAH and DALG $\alpha /$ MAGL ratios respectively (Guo et al. 2005, Wang et al. 2007, Fonseca et al. 2010a). Thus, DALG $\alpha$ and MAGL are distributed during the implantation process in a way that minimizes the excessive exposure to high levels of 2-AG (Wang et al. 2007, Fonseca et al. 2010b). Nevertheless, the role of 2-AG during different stages of pregnancy is not completely understood. On the other hand, Guo and coworkers (2005) have shown that on days $1-4$ of pregnancy in mice, NAPE-PLD is highly expressed in the luminal and glandular epithelium of the uterus compared with the stroma, suggesting that the epithelium is the major source of endocannabinoids before implantation. Nevertheless, on days 5-7 of pregnancy, NAPE-PLD is expressed only by luminal and glandular epithelial cells in the interimplantation sites together with a very low expression of this enzyme in the sites of blastocyst implantation. The opposite is true for uterine FAAH expression; its levels are higher at implantation sites and lower at interimplantations sites (Wang et al. 2007). As a result, higher levels of AEA are present in the interimplantation than at implantation sites (Paria et al. 2001, Guo et al. 2005) (Fig. 2). It has been hypothesized that the embryo plays a role in regulating the uterine endocannabinoid tone by releasing, a yet to be characterized, 'FAAH activator' that decreases the uterine NAPE-PLD/FAAH ratio, reducing AEA levels at the implantation site (Maccarrone et al. 2004). Accordingly, it has been shown that lysophosphatidic acid induces the expression of FAAH during the implantation window (day 5 of gestation) in rats (Sordelli et al. 2012a) and that the presence of the embryo is required for AEA action on uterine nitric oxide synthase activity (Sordelli et al. 2011). Moreover, to minimize the exposure to toxic levels of AEA, the blastocyst approaching implantation regulates its expression of CB1. Thus, it has been shown that blastocysts collected from the uterus on the morning of day 4 of pregnancy expressed higher levels of AEA

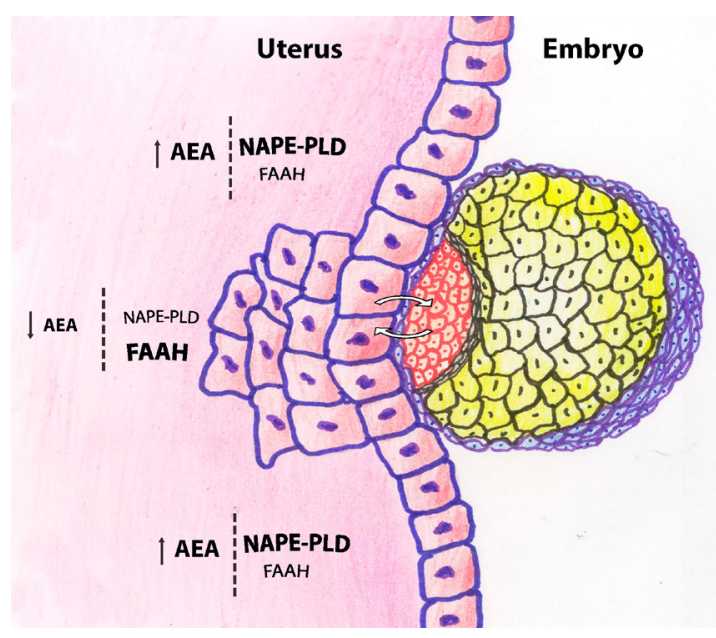

Figure 2 Schematic representation of the feto-maternal interface and the role of the endocannabinoid signaling during implantation according to rodent and human studies (adapted and modified from Fonseca et al. 2013a). The process of implantation requires a highly synchronized and complex bidirectional communication between the conceptus and the endometrium. The endocannabinoid system (eCS) plays an important role during the process of implantation. A delicate balance between anandamide (AEA) synthesis (driven mainly by NAPE-PLD) and degradation (mainly by FAAH) is necessary to ensure an appropriate 'AEA tone' during implantation. The implantation site presents low levels of AEA by highly expressing FAAH together with a low expression of NAPE-PLD. In contrast, the adjacent tissue presents high levels of AEA by expressing high levels of NAPE-PLD and low levels of FAAH. 
binding sites compared with blastocysts recovered on the evening of day 4 , before the attachment reaction (Paria et al. 2001). It has been reported that activated blastocysts show higher expression of CB1 than dormant blastocysts (Wang \& Dey 2005). Thus, AEA levels are tightly regulated in human pregnancy, showing no variations during the first and second trimesters (Lam et al. 2008). Conversely, elevated serum levels of AEA are found in women with nonviable first-trimester pregnancy compared with those in women with viable pregnancies (Taylor et al. 2011). Similarly, Habayeb and coworkers $(2008 a, b)$ found higher plasma levels of AEA in women prone to miscarriage compared with those in the normal birth group. Contrariwise, Tong and coworkers (2012) found no differences between the plasma levels of AEA of asymptomatic women at 6-10 weeks of gestation who miscarried and those who did not. Nevertheless, Maccarrone and coworkers $(2003 a, b)$ have shown that high levels of AEA are correlated with low levels of progesterone, which is associated with implantation failure and/or abnormal development of the feto-maternal interface that eventually leads to miscarriage. Indeed, progesterone has been shown to stimulate FAAH activity in human peripheral lymphocytes (Maccarrone et al. 2001a), with these cells playing a crucial role during human embryo implantation. Lipopolysaccharide (LPS), the main component of Gram-negative bacteria frequently associated with maternal infection and pregnancy loss, not only reduces FAAH activity and increases the production of AEA in human lymphocytes (Maccarrone et al. 2001 b) and murine macrophages (Liu et al. 2003), but also causes a serum progesterone withdrawal in 7-day pregnant mice (Aisemberg et al. 2013) changes that were associated with miscarriage. Data from our laboratory have shown that progesterone supplementation to LPS-treated pregnant mice restores FAAH activity in murine peripheral mononuclear cells (Wolfson et al. 2013). Accordingly, Maccarrone and coworkers (2000b) reported that FAAH activity in human peripheral lymphocytes was lower in women who had spontaneous miscarriages than in those who did not. In fact, increased AEA levels are also found in the peripheral blood of women with ectopic pregnancy together with a reduced FAAH activity in peripheral lymphocytes (Gebeh et al. 2013). Similarly, women subjected to in vitro fertilization (IVF) or intracytoplasmatic sperm injection (ICSI) and become pregnant show low levels of serum AEA at the time of implantation in comparison with those who did not (El-Talatini et al. 2009a). Furthermore, Faah ${ }^{-/-}$ mice, which have higher oviductal AEA levels also show impaired embryo transport through the oviduct (Wang et al. 2006b). This seems to be due to maternal and not embryonic defects because the embryo can implant in day 4 pseudopregnant uteri (Wang et al. 2004, Sun \& Dey 2008). Interestingly, Faah ${ }^{-/}$embryo exhibits retarded development (Wang et al. 2006b, Xie et al. 2012).

Regarding the expression of cannabinoid receptor during the implantation stage, it is shown that both CB1 and CB2 are expressed in nonpregnant human endometrium (Taylor et al. 2010) as well as in rat endometrium during early pregnancy (Fonseca et al. 2009). A reduced expression of CB1 in fallopian tubes is associated with ectopic pregnancy (Horne et al. 2008). It has been proposed that $\mathrm{CB} 1$ plays an important role in embryo transport because $\mathrm{Cb}^{1^{--}}$and $\mathrm{Cb}^{-/-} \mathrm{Cb}^{-/-}$but not $C b 2^{-/-}$mice show oviductal retention (Wang et al. 2004), suggesting that the lack of CB1 is responsible for this phenomenon. Moreover, wild-type mice pharmacologically treated with CB1 antagonist, but not CB2 antagonists, also show high rates of embryo retention in the oviduct.

\section{The endocannabinoid system during early pregnancy}

Once the blastocyst comes in contact with the endometrial layer of the uterus, the endometrial stromal cells undergo a series of morphological changes (known as decidualization), which prepare the uterus for trophoblast invasion.

In humans, decidualization happens in the normal menstrual cycle during the luteal phase (Salamonsen et al. 2003). Interestingly, during the luteal phase, the levels of plasma AEA are lower than those in the follicular phase (Habayeb et al. 2004), which suggest that steroid hormones are involved in the regulation of AEA levels in human pregnancy. However, in rodents, decidualization only occurs when the blastocyst is in close contact with the endometrium (Fonseca et al. 2012), with stromal cells proliferating and differentiating into decidual cells. Abnormalities during the process of decidualization are associated with increased risk of pregnancy complications, miscarriage, preeclampsia, fetal growth restriction and preterm labor (Fonseca et al. 2013a).

Several studies have provided evidence of the expression of CB1, CB2, NAPE-PLD and FAAH in decidua of women with viable pregnancies (Habayeb et al. 2004) as well as in rodents (Fonseca et al. 2009, 2010a, Taylor et al. 2011) suggesting the role of the endocannabinoid system in the process of decidual differentiation and remodeling. Fonseca et al. (2009) have shown that CB1 expression is markedly upregulated during midpregnancy in rats, a period of maximal decidual development. After reaching its maximum development, the decidua undergoes regression with apoptosis playing a crucial role (Gu et al. 1994, Dai et al. 2000). Pharmacological activation of CB1 receptor with the synthetic cannabinoid WIN 55,212-2 inhibits the induction of human decidual cell differentiation and induces apoptosis by a cAMP-dependent mechanism (Moghadam et al. 2005). Thus, AEA and 2-AG were 
described as proapoptotic lipids in primary rat decidual cell cultures (Fonseca et al. 2009, 2010b). Therefore, an 'endocannabinoid tone' needs to be tightly maintained to avoid the toxic effects on the changing decidua. Low levels of AEA induce morphological and molecular changes characteristic of an apoptotic cell death, whereas higher concentrations are associated with an increased release of lactate dehydrogenase, characteristic of a necrotic process (Fonseca et al. 2009). Interestingly, these effects were reversed by blocking CB1, but not CB2 or TRPV1. Activation of CB1 results in de novo synthesis of ceramide and signaling via p38 MAPK phosphorylation, which leads to mitochondrial stress and ROS production and subsequently, apoptosis (Fonseca et al. 2013b). The fact that increased levels of AEA exert toxic effects on decidua via activation of CB1 receptor is corroborated by our observation that $\mathrm{Cb}^{-/-}$mice are resistant to LPS-induced early embryo loss and presented a greater number of pups per litter (Wolfson et al. 2015). Conversely, Horne and coworkers (2008) have found that women with ectopic pregnancy show low decidual expression of CB1, and Wang and coworkers (2004) reported impaired oviductal transport in $\mathrm{Cb}^{-/-}$mice. Therefore, a lack of expression of CB1 might be beneficial in protecting the pregnancy from inflammation but might predispose to other pathologies. The role of CB2 on decidual cells is, however, much less clear. It has been reported that high concentrations of AEA induces, via a CB2-dependent mechanism, inhibition of proliferation of the human choriocarcinoma cell line BeWo, a model of first-trimester trophoblast (Trabucco et al. 2009). We have shown that high levels of AEA stimulate nitric oxide $(\mathrm{NO})$ synthesis on murine decidua in response to LPS and that these effects were abrogated by blocking either CB1 or CB2 (Vercelli et al. 2009). Moreover, AEA and its nonhydrolyzable analog, methanandamide, modulate the LPS-induced synthesis of prostaglandins in uterine explants from pregnant mice (Vercelli et al. 2012). Furthermore, LPS administration to 7-day pregnant mice induces a decrease in decidual FAAH activity (Wolfson et al. 2015). Our observations point toward the endocannabinoid system as a mediator of the deleterious effects of LPS in reproductive events.

As it has been previously mentioned, FAAH is the main catabolic enzyme for the degradation of AEA into arachidonic acid and ethanolamine, providing a source for prostaglandin synthesis. As decidual FAAH might be downregulated during maternal infections (Wolfson et al. 2015), AEA could be a direct substrate to COX-2 oxidative metabolism to produce prostaglandin-like compounds called prostaglandin-ethanolamides or 'prostamides' (PMs). Indeed, Almada and coworkers (2015) have recently shown that AEA is metabolized into prostamide-E2 (PME2) in rat decidual cells when FAAH is inhibited. PME2 mimics the proapoptotic actions of AEA on decidual cells (Almada et al. 2015). Prostamides are up to 3-fold higher in AEA-treated tissues from Faah ${ }^{-1-}$-mice compared with their wild-type counterparts (Weber et al. 2004). These findings provide evidence that low FAAH activity resulting in increased prostamide concentrations might have a deleterious impact on pregnancy.

Interestingly, the interaction between AEA and COX-2 seems to be far more complex because several reports indicate that AEA is capable of modulating prostaglandin production. Thus, in the amnion, AEA acts via CB1 to increase $\mathrm{PGE}_{2}$ levels (Mitchell et al. 2008), whereas it exerts opposite effects on uterine $\mathrm{PGE}_{2}$ and $\mathrm{PGF}_{2 \alpha}$ biosynthesis, by inhibiting $\mathrm{PGE}_{2}$ production and increasing PGF PG $_{2 \alpha}$ levels (Vercelli et al. 2012). Similarly, COX-2-derived prostaglandins mediate the inhibitory effect of AEA on NOS activity in the receptive rat uterus (Sordelli et al. 2012b). The endocannabinoid system appears to be at the center of an intricate biochemical cross talk that further complicates the understanding of its role in the physiology and pathology of pregnancy.

Alterations in endocannabinoid signaling are associated with early pregnancy loss, although disparate results have been reported. No differences were found in the expression of NAPE-PLD in the trophoblast, mesenchymal core or placental decidua from spontaneous miscarriages compared with placentae from elective surgical termination (Taylor et al. 2011). Contrarily, Trabucco and coworkers (2009) have found a 2-fold increase in Nape-pld mRNA expression in the first trimester (weeks 9-12) placentae from elective abortions than in that from spontaneous miscarriage. This observation would suggest that before a miscarriage, there are low levels of AEA in placenta, which is in stark contrast to the reports that women at high risk of miscarriage present high plasma levels of AEA (Habayeb et al. 2004, 2008a, Taylor et al. 2011). On the other hand, Tong and coworkers (2012) have failed to find differences in plasma AEA levels between women with normal pregnancy and women who subsequently miscarried. Conversely, it has been found that FAAH is more abundant in the decidual stromal cells of women with recurrent miscarriage than in the placenta from normal pregnancies (Chamley et al. 2008). No differences, however, have been found in FAAH expression on trophoblast cells from women with normal pregnancy and recurrent miscarriage (Chamley et al. 2008). Collectively, these observations suggest that the expression of the endocannabinoid system is time and tissue specific and that alterations in this system are associated with early pregnancy loss.

\section{Endocannabinoid system during placentation}

Once the peak phase of decidualization ends, placentation begins to establish maternal-fetal circulation. The placenta requires a proper number and distribution of the different trophoblastic cells to perform its physiological functions. Changes in trophoblast 
proliferation, differentiation and/or distribution lead to an abnormal placentation.

The major endocannabinoids AEA and 2-AG are detected in murine placentae. Indeed, $\mathrm{Faah}^{-/}$ mice, but not $\mathrm{Cb}^{-1-}$ mice, show high levels of placental AEA, supporting the hypothesis that FAAH is the major metabolic gatekeeper of AEA levels. Immunohistochemical analysis has shown that FAAH and CB1 are expressed on ectoplacental cone (EPC) on day 10 of pregnancy and the spongiotrophoblast cells (SPT) layer on day 14 (Sun et al. 2010). Moreover, CB1 and FAAH are shown to be expressed in human amniotic epithelial cells, chorionic cytotrophoblasts (Park et al. 2003) and syncytiotrophoblasts (Habayeb et al. 2008b). AEA metabolic enzymes are also expressed during human placental development (Chamley et al. 2008, Taylor et al. 2011), and the whole eCS is shown to be present in murine placentae (Sun et al. 2010). Different lines of research have provided evidence that altered expression of NAPE-PLD, CB1 and FAAH in the firsttrimester placentae and high levels of AEA are associated with an endangered pregnancy outcome (Park et al. 2003, Trabucco et al. 2009, Meccariello et al. 2014). Altered levels of AEA influence trophoblast invasion (Sun et al. 2010) and proliferation (Xie et al. 2012). Furthermore, higher plasma levels of AEA are detected in women with nonviable pregnancies (Taylor et al. 2011). However, in rats, at the peak of decidua development, high NAPE-PLD activity increases AEA levels, which are involved in decidua remodeling (Fonseca et al. 2013a,b, 2014). Notwithstanding, FAAH activity prevails during placentation (Fonseca et al. 2014), giving further support to the hypothesis that this enzyme is the key regulator of AEA levels (Fig. 3).

Placentation is shown to be compromised in $\mathrm{Cb}^{-/-}$ mice. These animals show lower placental weight on days 12 and 14 than WT mice (Sun et al. 2010) and show a retarded development of the SPT layer. Abnormal endocannabinoid signaling affects the proliferation of trophoblast progenitor cells in the EPC, which later differentiate into SPT cells (Sun \& Dey 2012). Cb1 $1^{-/-}$ trophoblast progenitor cell proliferation is much reduced, whereas $\mathrm{Faah}^{-/-}$trophoblast progenitor cell proliferation is only mildly reduced (Sun \& Dey 2012). Accordingly, trophoblast stem cells (TSCs) from WT mice treated with methanandamide show a faster proliferation rate, which is attenuated by the selective antagonism of CB1 (Sun et al. 2010). In contrast, other reports show that AEA not only prevents BeWo trophoblast cell proliferation in a dose-dependent manner (Habayeb et al. 2008b) but also induces apoptosis (Costa et al. 2015). Similar to AEA, Costa and coworkers (2014) have described the expression of 2-AG metabolic enzymes in human cytotrophoblasts and in BeWo cells. Furthermore, 2-AG has been shown to induce apoptosis in these cells via a CB2 receptor-dependent mechanism (Costa et al. 2014).

Interestingly, $\mathrm{Cb}^{-/-}$and $\mathrm{Faah}^{-/-}$placentae show an abnormal differentiation of trophoblast precursor cells, which are more prone to differentiate into trophoblast giant cells (TGCs) in detriment of the spongiotrophoblast cells (Sun et al. 2010). Reciprocal embryo transfer experiments between $\mathrm{Cb}^{-/-}$and WT mice have shown that there is a lack of CB1 in the embryo that provokes this biased trophoblast differentiation (Sun et al. 2010). Pharmacological blockade of CB1 receptor on days 8 and 9 of pregnancy, when placentation begins, further confirms the previous observation. Indeed, treatment with SR14716A (a CB1 antagonist) reduces the number of SPT cells in WT placentae. Furthermore, invasive capacity of the trophoblast cells of the maternal decidual zone to reshape and redirect the maternal blood vessels to support embryo growth is critical for a successful pregnancy (Cross et al. 2002). It has been shown that the invasion of glycogen trophoblast cells

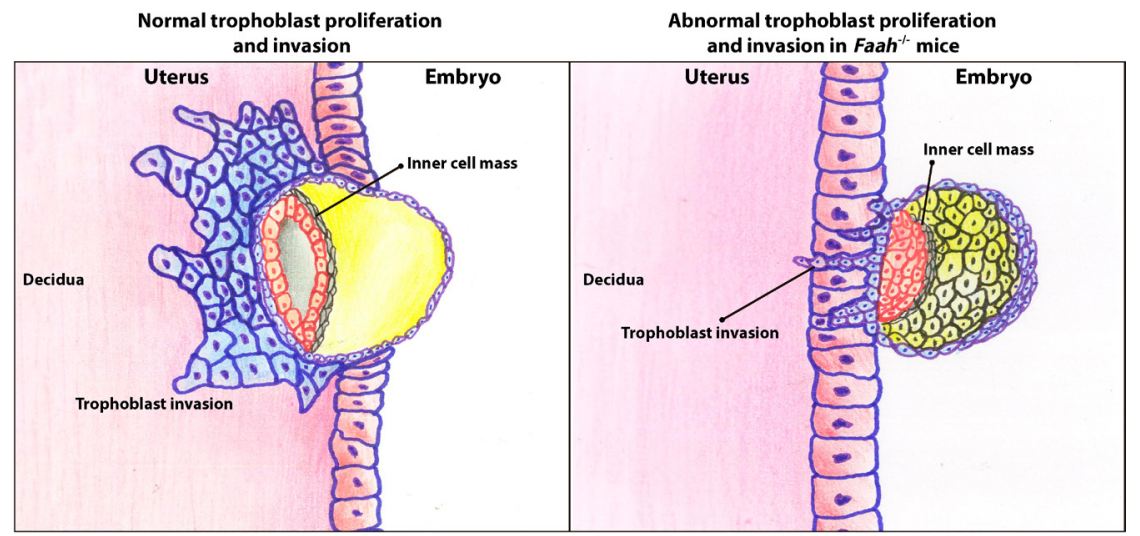

Figure 3 Schematic representation of the feto-maternal interface and the role of the endocannabinoid signaling during trophoblast proliferation and invasion according to studies in FAAH-deficient mice (adapted and modified from Fonseca et al. 2013a). Trophoblast proliferation and invasion are compromised in Faah ${ }^{-/}$mice suggesting an important role of the endocannabinoid system in these processes. Placentae from $\mathrm{FAAH}^{-/-}$mice show an abnormal differentiation of trophoblast precursor cells, which are more prone to differentiate into trophoblast giant cells (TGCs) in detriment of the spongiotrophoblast cells (SPT). This biased trophoblast differentiation compromises the invasive capacity of these cells to reshape and redirect the maternal blood vessels to support embryo growth, representing a risk for the pregnancy outcome. 
(GTC) into the decidua basalis is highly reduced in $\mathrm{Cb}^{-/-}$mice compared with WT mice (Sun et al. 2010). These observations further support the hypothesis that an appropriate endocannabinoid signaling is required for the correct placental development and excessively high levels of endocannabinoids are toxic to trophoblast cells, therefore represents a risk factor for the firsttrimester miscarriages (Habayeb et al. 2008b).

\section{Final remarks}

With the increasing number of countries decriminalizing, and even legalizing, the recreational use of cannabis, there is a critical need for understanding the effects of this drug in female fertility and the involvement of the eCS in the pathophysiology of the different stages of pregnancy. This is particularly important in the case of women seeking pregnancy who consume cannabis for medical reasons (such as treatment of nausea and vomiting, reduction of symptoms associated with some neurological diseases, reduction of intraocular pressure in glaucoma and treatment of depression and pain). The evidence presented here shows that alterations in the eCS lead to poor pregnancy outcomes: poor blastocyst implantation, inhibition of decidualization, retardation in embryo development, miscarriage and compromised placentation. Although targeting the endocannabinoid system represents an attractive pharmacological strategy to maintain a healthy pregnancy, the intrinsic promiscuity of this system makes it difficult for the development of therapeutic drugs and/or to predict their effects. Overall, the expression/activity of the several components of the endocannabinoid system (NAPEPLD, CB1, CB2 and FAAH) must be tightly regulated to keep it at physiological levels at every stage of pregnancy, from implantation to parturition, to prevent the negative effects during this period and to assure a healthy pregnancy. As onset of labor approaches, AEA levels increase dramatically. In any case, the enzyme FAAH seems to be the 'metabolic checkpoint' of endocannabinoid activity. Future research efforts should be directed to understand the complex interaction of this system.

\section{Declaration of interest}

The authors declare that there is no conflict of interest that could be perceived as prejudicing the impartiality of the research reported.

\section{Funding}

F C was supported by Agencia Nacional para la Promoción Científica y Tecnológica (PICT 2012/1220). J A was supported by Agencia Nacional para la Promoción Científica y Tecnológica (PICT 2010/0938). A M F was supported by
Agencia Nacional para la Promoción Científica y Tecnológica (PICT 2010/0813 and PICT 2013/0097) and Consejo Nacional de Investigaciones Científicas y Técnicas (PIP 2012/0061).

\section{References}

Aisemberg J, Vercelli CA, Bariani M V, Billi SC, Wolfson ML \& Franchi AM 2013 Progesterone is essential for protecting against LPS-induced pregnancy loss. LIF as a potential mediator of the anti-inflammatory effect of progesterone. PLOS ONE 8 e56161. (doi:10.1371/journal. pone.0056161)

Almada M, Piscitelli F, Fonseca BM, Di Marzo V, Correia-da-Silva G \& Teixeira N 2015 Anandamide and decidual remodelling: COX-2 oxidative metabolism as a key regulator. Biochimica et Biophysica Acta 1851 1473-1481. (doi:10.1016/j.bbalip.2015.08.011)

Battista N, Rapino C, Di Tommaso M, Bari M, Pasquariello N \& Maccarrone M 2008 Regulation of male fertility by the endocannabinoid system. Molecular and Cellular Endocrinology 286 S17-S23. (doi:10.1016/j.mce.2008.01.010)

Begg M, Mo FM, Offertáler L, Bátkai S, Pacher P, Razdan RK, Lovinger DM \& Kunos G 2003 G protein-coupled endothelial receptor for atypical cannabinoid ligands modulates a Ca2+-dependent $\mathrm{K}+$ current. Journal of Biological Chemistry 278 46188-46194. (doi:10.1074/jbc. M307258200)

Di Blasio AM, Vignali M \& Gentilini D 2013 The endocannabinoid pathway and the female reproductive organs. Journal of Molecular Endocrinology 50 R1-R9. (doi:10.1530/JME-12-0099)

Bouaboula M, Poinot-Chazel C, Bourrié B, Canat X, Calandra B, RinaldiCarmona M, Le Fur G \& Casellas P 1995 Activation of mitogen-activated protein kinases by stimulation of the central cannabinoid receptor CB1. Biochemical Journal 312 637-641. (doi:10.1042/bj3120637)

Bouaboula $\mathbf{M}$, Desnoyer $\mathbf{N}$, Carayon $\mathbf{P}$, Combes $\mathbf{T} \&$ Casellas $\mathbf{P}$ 1999 Gi protein modulation induced by a selective inverse agonist for the peripheral cannabinoid receptor CB2: implication for intracellular signalization cross-regulation. Molecular Pharmacology 55 473-480.

Burstein SH, Rossetti RG, Yagen B \& Zurier RB 2000 Oxidative metabolism of anandamide. Prostaglandins \& Other Lipid Mediators $6129-41$. (doi:10.1016/s0090-6980(00)00053-8)

Caulfield MP \& Brown DA 1992 Cannabinoid receptor agonists inhibit Ca current in NG108-15 neuroblastoma cells via a pertussis toxinsensitive mechanism. British Journal of Pharmacology 106 231-232. (doi:10.1111/j.1476-5381.1992.tb14321.x)

Chamley LW, Bhalla A, Stone PR, Liddell H, O'Carroll S, Kearn C \& Glass M 2008 Nuclear localisation of the endocannabinoid metabolizing enzyme fatty acid amide hydrolase (FAAH) in invasive trophoblasts and an association with recurrent miscarriage. Placenta 29 970-975. (doi:10.1016/j.placenta.2008.08.003)

Cobellis G, Cacciola G, Scarpa D, Meccariello R, Chianese R, Franzoni MF, Mackie K, Pierantoni R \& Fasano S 2006 Endocannabinoid system in frog and rodent testis: type- 1 cannabinoid receptor and fatty acid amide hydrolase activity in male germ cells. Biology of Reproduction 75 82-89. (doi:10.1095/biolreprod.106.051730)

Correa F, Mestre L, Docagne F \& Guaza C 2005 Activation of cannabinoid CB2 receptor negatively regulates $\mathrm{IL}-12 \mathrm{p} 40$ production in murine macrophages: role of IL-10 and ERK1/2 kinase signaling. British Journal of Pharmacology 145 441-448. (doi:10.1038/sj.bjp.0706215)

Correa F, Docagne F, Mestre L, Clemente D, Hernangómez M, Loría F \& Guaza C 2009 A role for CB2 receptors in anandamide signalling pathways involved in the regulation of IL-12 and IL-23 in microglial cells. Biochemical Pharmacology 77 86-100. (doi:10.1016/j. bcp.2008.09.014)

Costa MA, Fonseca BM, Keating E, Teixeira NA \& Correia-Da-Silva G 2014 2-Arachidonoylglycerol effects in cytotrophoblasts: metabolic enzymes expression and apoptosis in BeWo cells. Reproduction 147 301-311. (doi:10.1530/REP-13-0563)

Costa MA, Fonseca BM, Teixeira NA \& Correia-da-Silva G 2015 The endocannabinoid anandamide induces apoptosis in cytotrophoblast cells: involvement of both mitochondrial and death receptor pathways. Placenta 36 69-76. (doi:10.1016/j.placenta.2014.10.011) 
Cravatt BF, Giang DK, Mayfield SP, Boger DL, Lerner RA \& Gilula NB 1996 Molecular characterization of an enzyme that degrades neuromodulatory fatty-acid amides. Nature 384 83-87. (doi:10.1038/384083a0)

Cross JC, Hemberger M, Lu Y, Nozaki T, Whiteley K, Masutani M \& Adamson SL 2002 Trophoblast functions, angiogenesis and remodeling of the maternal vasculature in the placenta. Molecular and Cellular Endocrinology 187 207-212. (doi:10.1016/S0303-7207(01)00703-1)

Dai D, Moulton BC \& Ogle TF 2000 Regression of the decidualized mesometrium and decidual cell apoptosis are associated with a shift in expression of Bcl2 family members. Biology of Reproduction $\mathbf{6 3}$ 188-195. (doi:10.1095/biolreprod63.1.188)

Das SK, Paria BC, Chakraborty I \& Dey SK 1995 Cannabinoid ligandreceptor signaling in the mouse uterus. PNAS $92 \quad 4332-4336$. (doi:10.1073/pnas.92.10.4332)

Devane WA, Hanus L, Breuer A, Pertwee RG, Stevenson LA, Griffin G, Gibson D, Mandelbaum A, Etinger A \& Mechoulam R 1992 Isolation and structure of a brain constituent that binds to the cannabinoid receptor. Science 258 1946-1949. (doi:10.1126/science.1470919)

Devane WA, Dysarz FA, Johnson MR, Melvin LS \& Howlett AC 1988 Determination and characterization of a cannabinoid receptor in rat brain. Molecular Pharmacology 34 605-613.

Di Marzo V, Fontana A, Cadas H, Schinelli S, Cimino G, Schwartz JC \& Piomelli D 1994 Formation and inactivation of endogenous cannabinoid anandamide in central neurons. Nature 372 686-691. (doi:10.1038/372686a0)

Dinh TP, Carpenter D, Leslie FM, Freund TF, Katona I, Sensi SL, Kathuria S \& Piomelli D 2002 Brain monoglyceride lipase participating in endocannabinoid inactivation. PNAS 99 10819-10824. (doi:10.1073/ pnas.152334899)

El-Talatini MR, Taylor AH \& Konje JC 2009a Fluctuation in anandamide levels from ovulation to early pregnancy in in-vitro fertilization-embryo transfer women, and its hormonal regulation. Human Reproduction $\mathbf{2 4}$ 1989-1998. (doi:10.1093/humrep/dep065)

El-Talatini MR, Taylor AH, Elson JC, Brown L, Davidson AC \& Konje JC $2009 \mathrm{~b}$ Localisation and function of the endocannabinoid system in the human ovary. PLOS ONE 4 e4579. (doi:10.1371/journal. pone.0004579)

El-Talatini MR, Taylor AH \& Konje JC 2010 The relationship between plasma levels of the endocannabinoid, anandamide, sex steroids, and gonadotrophins during the menstrual cycle. Fertility and Sterility 93 1989-1996. (doi:10.1016/j.fertnstert.2008.12.033)

Fonseca BM, Correia-da-Silva G, Taylor AH, Konje JC, Bell SC \& Teixeira NA 2009 Spatio-temporal expression patterns of anandamidebinding receptors in rat implantation sites: evidence for a role of the endocannabinoid system during the period of placental development. Reproductive Biology and Endocrinology 7 121. (doi:10.1186/14777827-7-121)

Fonseca BM, Correia-da-Silva G, Taylor AH, Lam PMW, Marczylo TH, Konje JC, Bell SC \& Teixeira NA 2010a N-acylethanolamine levels and expression of their metabolizing enzymes during pregnancy. Endocrinology 151 3965-3974. (doi:10.1210/en.2009-1424)

Fonseca BM, Correia-da-Silva G, Taylor AH, Lam PMW, Marczylo TH, Bell SC, Konje JC \& Teixeira NA 2010b The endocannabinoid 2-arachidonoylglycerol (2-AG) and metabolizing enzymes during rat fetoplacental development: a role in uterine remodelling. International Journal of Biochemistry \& Cell Biology 42 1884-1892. (doi:10.1016/ j.biocel.2010.08.006)

Fonseca BM, Correia-da-Silva G \& Teixeira NA 2012 The rat as an animal model for fetoplacental development: a reappraisal of the postimplantation period. Reproductive Biology 12 97-118. (doi:10.1016/ S1642-431X(12)60080-1)

Fonseca BM, Correia-Da-Silva G, Almada M, Costa MA \& Teixeira NA 2013a The endocannabinoid system in the postimplantation period: a role during decidualization and placentation. International Journal of Endocrinology 2013 510540. (doi:10.1155/2013/510540)

Fonseca BM, Correia-da-Silva G \& Teixeira NA 2013b The endocannabinoid anandamide induces apoptosis of rat decidual cells through a mechanism involving ceramide synthesis and p38 MAPK activation. Apoptosis $\mathbf{1 8}$ 1526-1535. (doi:10.1007/s10495-013-0892-9)

Fonseca BM, Battista N, Correia-da-Silva G, Rapino C, Maccarrone M \& Teixeira NA 2014 Activity of anandamide (AEA) metabolic enzymes in rat placental bed. Reproductive Toxicology 49 74-77. (doi:10.1016/j. reprotox.2014.07.078)
Franklin JM \& Carrasco GA 2013 Cannabinoid receptor agonists upregulate and enhance serotonin $2 \mathrm{~A}(5-\mathrm{HT}(2 \mathrm{~A}))$ receptor activity via ERK1/2 signaling. Synapse 67 145-159. (doi:10.1002/syn.21626)

Gammon CM, Freeman GM, Xie W, Xie W, Petersen SL \& Wetsel WC 2005 Regulation of gonadotropin-releasing hormone secretion by cannabinoids. Endocrinology 146 4491-4499. (doi:10.1210/ en.2004-1672)

Gebeh AK, Willets JM, Bari M, Hirst RA, Marczylo TH, Taylor AH, Maccarrone M \& Konje JC 2013 Elevated anandamide and related $\mathrm{N}$-acylethanolamine levels occur in the peripheral blood of women with ectopic pregnancy and are mirrored by changes in peripheral fatty acid amide hydrolase activity. Journal of Clinical Endocrinology and Metabolism 98 1226-1234. (doi:10.1210/jc.2012-3390)

Gebremedhin D, Lange AR, Campbell WB, Hillard CJ \& Harder DR 1999 Cannabinoid CB1 receptor of cat cerebral arterial muscle functions to inhibit L-type Ca2+ channel current. American Journal of Physiology 276 $\mathrm{H} 2085-\mathrm{H} 2093$.

Gu Y, Jow GM, Moulton BC, Lee C, Sensibar JA, Park-Sarge OK, Chen TJ \& Gibori G 1994 Apoptosis in decidual tissue regression and reorganization. Endocrinology 135 1272-1279. (doi:10.1210/ endo.135.3.8070373)

Guo Y, Wang H, Okamoto Y, Ueda N, Kingsley PJ, Marnett LJ, Schmid HHO, Das SK \& Dey SK 2005 N-acylphosphatidylethanolamine-hydrolyzing phospholipase D is an important determinant of uterine anandamide levels during implantation. Journal of Biological Chemistry 280 23429-23432. (doi:10.1074/jbc.C500168200)

Gye MC, Kang HH \& Kang HJ 2005 Expression of cannabinoid receptor 1 in mouse testes. Archives of Andrology 51 247-255. (doi:10.1080/014850190898845)

Habayeb OMH, Taylor AH, Evans MD, Cooke MS, Taylor DJ, Bell SC \& Konje JC 2004 Plasma levels of the endocannabinoid anandamide in women - a potential role in pregnancy maintenance and labor? Journal of Clinical Endocrinology and Metabolism 89 5482-5487. (doi:10.1210/ jc.2004-0681)

Habayeb OMH, Taylor AH, Finney M, Evans MD \& Konje JC 2008a Plasma anandamide concentration and pregnancy outcome in women with threatened miscarriage. JAMA 299 1135-1136. (doi:10.1001/ jama.299.10.1135)

Habayeb OMH, Taylor AH, Bell SC, Taylor DJ \& Konje JC 2008b Expression of the endocannabinoid system in human first trimester placenta and its role in trophoblast proliferation. Endocrinology 149 5052-5060. (doi:10.1210/en.2007-1799)

Hanus L, Abu-Lafi S, Fride E, Breuer A, Vogel Z, Shalev DE, Kustanovich I \& Mechoulam R 2001 2-arachidonyl glyceryl ether, an endogenous agonist of the cannabinoid CB1 receptor. PNAS 98 3662-3665. (doi:10.1073/ pnas.061029898)

Horne AW, Phillips JA, Kane N, Lourenco PC, McDonald SE, Williams ARW, Simon C, Dey SK \& Critchley HOD 2008 CB1 expression is attenuated in Fallopian tube and decidua of women with ectopic pregnancy. PLOS ONE 3 1-6. (doi:10.1371/journal.pone.0003969)

Huang SM, Bisogno T, Trevisani M, Al-Hayani A, De Petrocellis L, Fezza F, Tognetto M, Petros TJ, Krey JF, Chu CJ et al. 2002 An endogenous capsaicin-like substance with high potency at recombinant and native vanilloid VR1 receptors. PNAS 99 8400-8405. (doi:10.1038/ nature05482)

Karasu T, Marczylo TH, Maccarrone M \& Konje JC 2011 The role of sex steroid hormones, cytokines and the endocannabinoid system in female fertility. Human Reproduction Update 17 347-361. (doi:10.1093/ humupd/dmq058)

Klonoff-Cohen HS, Natarajan L \& Chen RV 2006 A prospective study of the effects of female and male marijuana use on in vitro fertilization (IVF) and gamete intrafallopian transfer (GIFT) outcomes. American Journal of Obstetrics and Gynecology 194 369-376. (doi:10.1016/j. ajog.2005.08.020)

Kozak KR, Crews BC, Morrow JD, Wang LH, Ma YH, Weinander R, Jakobsson PJ \& Marnett LJ 2002 Metabolism of the endocannabinoids, 2 -arachidonylglycerol and anandamide, into prostaglandin, thromboxane, and prostacyclin glycerol esters and ethanolamides. Journal of Biological Chemistry 277 44877-44885. (doi:10.1074/jbc. M206788200)

Lam PMW, Marczylo TH, El-Talatini M, Finney M, Nallendran V, Taylor AH \& Konje JC 2008 Ultra performance liquid chromatography tandem mass spectrometry method for the measurement of anandamide in 
human plasma. Analytical Biochemistry 380 195-201. (doi:10.1016/j. ab.2008.05.033)

Lazzarin N, Valensise H, Bari M, Ubaldi F, Battista N, Finazzi-Agrò A \& Maccarrone M 2004 Fluctuations of fatty acid amide hydrolase and anandamide levels during the human ovulatory cycle. Gynecological Endocrinology 18 212-218. (doi:10.1080/09513590410001692492)

Liu J, Bátkai S, Pacher P, Harvey-White J, Wagner JA, Cravatt BF, Gao B \& Kunos G 2003 Lipopolysaccharide induces anandamide synthesis in macrophages via CD14/MAPK/Phosphoinositide 3-Kinase/NF-кB independently of platelet-activating factor. Journal of Biological Chemistry 278 45034-45039. (doi:10.1074/jbc.M306062200)

Maccarrone M, De Felici M, Bari M, Klinger F, Siracusa G \& Finazzi-Agrò A 2000a Down-regulation of anandamide hydrolase in mouse uterus by sex hormones. European Journal of Biochemistry/FEBS 267 2991-2997. (doi:10.1046/j.1432-1033.2000.01316.x)

Maccarrone $M$, Valensise $H$, Bari $M$, Lazzarin $N$, Romanini $C$ \& Finazzi-Agrò A $2000 b$ Relation between decreased anandamide hydrolase concentrations in human lymphocytes and miscarriage. Lancet 355 1326-1329. (doi:10.1016/S0140-6736(00)02115-2)

Maccarrone $M$, Valensise $H$, Bari $M$, Lazzarin $N$, Romanini C \& Finazzi-Agrò A 2001a Progesterone up-regulates anandamide hydrolase in human lymphocytes: role of cytokines and implications for fertility. Journal of Immunology 166 7183-7189. (doi:10.4049/ jimmunol.166.12.7183)

Maccarrone M, De Petrocellis L, Bari M, Fezza F, Salvati S, Di Marzo V \& Finazzi-Agrò A 2001b Lipopolysaccharide downregulates fatty acid amide hydrolase expression and increases anandamide levels in human peripheral lymphocytes. Archives of Biochemistry and Biophysics 393 321-328. (doi:10.1006/abbi.2001.2500)

Maccarrone M, Cecconi S, Rossi G, Battista N, Pauselli R \& FinazziAgrò A 2003a Anandamide activity and degradation are regulated by early postnatal aging and follicle-stimulating hormone in mouse Sertoli cells. Endocrinology 144 20-28. (doi:10.1210/en.2002220544)

Maccarrone M, Bari M, Di Rienzo M, Finazzi-Agrò A \& Rossi A 2003b Progesterone activates fatty acid amide hydrolase (FAAH) promoter in human $\mathrm{T}$ lymphocytes through the transcription factor Ikaros: Evidence for a synergistic effect of leptin. Journal of Biological Chemistry 278 32726-32732. (doi:10.1074/jbc.M302123200)

Maccarrone M, DeFelici M, Klinger FG, Battista N, Fezza F, Dainese E, Siracusa G \& Finazzi-Agrò A 2004 Mouse blastocysts release a lipid which activates anandamide hydrolase in intact uterus. Molecular Human Reproduction 10 215-221. (doi:10.1093/molehr/gah034)

Mackie K \& Hille B 1992 Cannabinoids inhibit N-type calcium channels in neuroblastoma-glioma cells. PNAS 89 3825-3829. (doi:10.1073/ pnas.89.9.3825)

Matsuda LA, Lolait SJ, Brownstein MJ, Young AC \& Bonner TI 1990 Structure of a cannabinoid receptor and functional expression of the cloned cDNA. Nature 346 561-564. (doi:10.1038/346561a0)

Meccariello R, Battista N, Bradshaw HB \& Wang H 2014 Endocannabinoids and reproduction. International Journal of Endocrinology 2014 2-4. (doi:10.1155/2014/378069)

Mechoulam R \& Gaoni Y 1965 Hashish. IV. The isolation and structure of cannabinolic cannabidiolic and cannabigerolic acids. Tetrahedron 21 1223-1229. (doi:10.1016/0040-4020(65)80064-3)

Mechoulam R, Ben-Shabat S, Hanus L, Ligumsky M, Kaminski NE, Schatz AR, Gopher A, Almog S, Martin BR \& Compton DR 1995 Identification of an endogenous 2-monoglyceride, present in canine gut, that binds to cannabinoid receptors. Biochemical Pharmacology $\mathbf{5 0}$ 83-90. (doi:10.1016/0006-2952(95)00109-D)

Mitchell MD, Sato TA, Wang A, Keelan JA, Ponnampalam AP \& Glass M 2008 Cannabinoids stimulate prostaglandin production by human gestational tissues through a tissue- and CB1-receptor-specific mechanism. American Journal of Physiology. Endocrinology and Metabolism 294 E352-E356. (doi:10.1152/ajpendo.00495.2007)

Moghadam KK, Kessler CA, Schroeder JK, Buckley AR, Brar AK \& Handwerger S 2005 Cannabinoid receptor I activation markedly inhibits human decidualization. Molecular and Cellular Endocrinology 229 65-74. (doi:10.1016/j.mce.2004.09.007)

Munro S, Thomas KL \& Abu-Shaar M 1993 Molecular characterization of a peripheral receptor for cannabinoids. Nature 365 61-65. (doi:10.1038/365061a0)
Paria BC, Das SK \& Dey SK 1995 The preimplantation mouse embryo is a target for cannabinoid ligand-receptor signaling. PNAS 92 9460-9464. (doi:10.1073/pnas.92.21.9460)

Paria BC, Deutsch DD \& Dey SK 1996 The uterus is a potential site for anandamide synthesis and hydrolysis: differential profiles of anandamide synthase and hydrolase activities in the mouse uterus during the periimplantation period. Molecular Reproduction and Development 45 183-192. (doi:10.1002/(SICl)1098-2795(199610)45:2\&lt;183:: AID-MRD11\&gt;3.0.CO;2-2)

Paria BC, Song H, Wang X, Schmid PC, Krebsbach RJ, Schmid HHO, Bonner TI, Zimmer A \& Dey SK 2001 Dysregulated cannabinoid signaling disrupts uterine receptivity for embryo implantation. Journal of Biological Chemistry 276 20523-20528. (doi:10.1074/jbc.M100679200)

Park B, Gibbons HM, Mitchell MD \& Glass M 2003 Identification of the CB1 cannabinoid receptor and fatty acid amide hydrolase (FAAH) in the human placenta. Placenta 24 990-995. (doi:10.1016/S01434004(03)00165-6)

Park B, McPartland JM \& Glass M 2004 Cannabis, cannabinoids and reproduction. Prostaglandins, Leukotrienes, and Essential Fatty Acids $\mathbf{7 0}$ 189-197. (doi:10.1016/j.plefa.2003.04.007)

Porter AC 2002 Characterization of a novel endocannabinoid, virodhamine, with antagonist activity at the CB1 receptor. Journal of Pharmacology and Experimental Therapeutics 301 1020-1024. (doi:10.1124/jpet.301.3.1020)

Prescott SM \& Majerus PW 1983 Characterization of 1,2-diacylglycerol hydrolysis in human platelets. Demonstration of an arachidonoylmonoacylglycerol intermediate. Journal of Biological Chemistry 258 764-769.

Rossato M, Ion Popa F, Ferigo M, Clari G \& Foresta C 2005 Human sperm express cannabinoid receptor $\mathrm{Cb} 1$, the activation of which inhibits motility, acrosome reaction, and mitochondrial function. Journal of Clinical Endocrinology and Metabolism 90 984-991. (doi:10.1210/ jc.2004-1287)

Ryberg E, Larsson N, Sjögren S, Hjorth S, Hermansson N-O, Leonova J, Elebring T, Nilsson K, Drmota T \& Greasley PJ 2007 The orphan receptor GPR55 is a novel cannabinoid receptor. British Journal of Pharmacology 152 1092-1101. (doi:10.1038/sj.bjp.0707460)

Salamonsen LA, Dimitriadis E, Jones RL \& Nie G 2003 Complex regulation of decidualization: a role for cytokines and proteases - a review. Placenta 24 S76-S85. (doi:10.1053/plac.2002.0928)

Sánchez C, Galve-Roperh I, Rueda D \& Guzmán M 1998 Involvement of sphingomyelin hydrolysis and the mitogen-activated protein kinase cascade in the Delta9-tetrahydrocannabinol-induced stimulation of glucose metabolism in primary astrocytes. Molecular Pharmacology 54 834-843.

Schmid PC, Paria BC, Krebsbach RJ, Schmid HH \& Dey SK 1997 Changes in anandamide levels in mouse uterus are associated with uterine receptivity for embryo implantation. PNAS 94 4188-4192. (doi:10.1073/ pnas.94.8.4188)

Schuel H, Burkman LJ, Lippes J, Crickard K, Forester E, Piomelli D \& Giuffrida A 2002 N-Acylethanolamines in human reproductive fluids. Chemistry and Physics of Lipids 121 211-227. (doi:10.1016/S00093084(02)00158-5)

Scotchie JG, Savaris RF, Martin CE \& Young SL 2015 Endocannabinoid regulation in human endometrium across the menstrual cycle. Reproductive Sciences 22 113-123. (doi:10.1177/1933719114533730)

Sharir H \& Abood ME 2010 Pharmacological characterization of GPR55, a putative cannabinoid receptor. Pharmacology \& Therapeutics 126 301-313. (doi:10.1016/j.pharmthera.2010.02.004)

Slipetz DM, O'Neill GP, Favreau L, Dufresne C, Gallant M, Gareau Y, Guay D, Labelle M \& Metters KM 1995 Activation of the human peripheral cannabinoid receptor results in inhibition of adenylyl cyclase. Molecular Pharmacology 48 352-361.

Sordelli MS, Beltrame JS, Burdet J, Zotta E, Pardo R, Cella M, Franchi AM \& Ribeiro ML 2011 The effect of Anandamide on uterine nitric oxide synthase activity depends on the presence of the blastocyst. PLOS ONE 6 e18368. (doi:10.1371/journal.pone.0018368)

Sordelli MS, Beltrame JS, Cella M, Gervasi MG, Perez Martinez S, Burdet J, Zotta E, Franchi AM \& Ribeiro ML 2012a Interaction between lysophosphatidic acid, prostaglandins and the endocannabinoid system during the window of implantation in the rat uterus. PLOS ONE 7 e46059. (doi:10.1371/journal.pone.0046059) 
Sordelli MS, Beltrame JS, Cella M, Franchi AM \& Ribeiro ML 2012b Cyclooxygenase-2 prostaglandins mediate anandamide-inhibitory action on nitric oxide synthase activity in the receptive rat uterus. European Journal of Pharmacology 685 174-179. (doi:10.1016/j. ejphar.2012.04.034)

Sugiura T, Kondo S, Sukagawa A, Nakane S, Shinoda A, Itoh K, Yamashita A \& Waku K 1995 2-Arachidonoylglycerol: a possible endogenous cannabinoid receptor ligand in brain. Biochemical and Biophysical Research Communications 215 89-97. (doi:10.1006/ bbrc.1995.2437)

Sugiura T, Kondo S, Sukagawa A, Tonegawa T, Nakane S, Yamashita A \& Waku K 1996 Enzymatic synthesis of anandamide, an endogenous cannabinoid receptor ligand, through $\mathrm{N}$-acylphosphatidylethanolamine pathway in testis: involvement of $\mathrm{Ca}(2+)$-dependent transacylase and phosphodiesterase activities. Biochemical and Biophysical Research Communications 218 113-117. (doi:10.1006/bbrc.1996.0020)

Sun X \& Dey SK 2008 Aspects of endocannabinoid signaling in periimplantation biology. Molecular and Cellular Endocrinology 286 S3-S11. (doi:10.1016/j.mce.2008.01.002)

Sun X \& Dey SK 2009 Cannabinoid/Endocannabinoid signaling impact on early pregnancy events. Current Topics in Behavioral Neurosciences 1 255-273. (doi:10.1007/978-3-540-88955-7_10)

Sun X \& Dey SK 2012 Endocannabinoid signaling in female reproduction. ACS Chemical Neuroscience 3 349-355. (doi:10.1021/cn300014e)

Sun Y, Alexander SPH, Kendall DA \& Bennett AJ 2006 Cannabinoids and PPARalpha signalling. Biochemical Society Transactions 34 1095-1097. (doi:10.1042/BST0341095)

Sun X, Xie H, Yang J, Wang H, Bradshaw HB \& Dey SK 2010 Endocannabinoid signaling directs differentiation of trophoblast cell lineages and placentation. PNAS 107 16887-16892. (doi:10.1073/ pnas.1010892107)

Syed SK, Bui HH, Beavers LS, Farb TB, Ficorilli J, Chesterfield AK, Kuo MS, Bokvist K, Barrett DG \& Efanov AM 2012 Regulation of GPR119 receptor activity with endocannabinoid-like lipids. American Journal of Physiology. Endocrinology and Metabolism 303 E1469-E1478. (doi:10.1152/ajpendo.00269.2012)

Taylor AH, Abbas MS, Habiba MA \& Konje JC 2010 Histomorphometric evaluation of cannabinoid receptor and anandamide modulating enzyme expression in the human endometrium through the menstrual cycle. Histochemistry and Cell Biology 133 557-565. (doi:10.1007/ s00418-010-0695-9)

Taylor A, Finney M, Lam P \& Konje J 2011 Modulation of the endocannabinoid system in viable and non-viable first trimester pregnancies by pregnancy-related hormones. Reproductive Biology and Endocrinology 9 152. (doi:10.1186/1477-7827-9-152)

Tong S, Ngian GL, Onwude JL, Permezel M, Saglam B, Hay S, Konje JC, Marczylo TH, Fleming G, Walker SP et al. 2012 Diagnostic accuracy of maternal serum macrophage inhibitory cytokine-1 and pregnancyassociated plasma protein-A at 6-10 weeks of gestation to predict miscarriage. Obstetrics \& Gynecology 119 1000-1008. (doi:10.1097/ aog.0b013e3182518fd3)

Trabucco E, Acone G, Marenna A, Pierantoni R, Cacciola G, Chioccarelli T, Mackie K, Fasano S, Colacurci N, Meccariello R et al. 2009 Endocannabinoid system in first trimester placenta: low FAAH and high CB1 expression characterize spontaneous miscarriage. Placenta 30 516-522. (doi:10.1016/j.placenta.2009.03.015)

Urquhart P, Nicolaou A \& Woodward DF 2015 Endocannabinoids and their oxygenation by cyclo-oxygenases, lipoxygenases and other oxygenases. Biochimica et Biophysica Acta 1851 366-376. (doi:10.1016/ j.bbalip.2014.12.015)

Vercelli CA, Aisemberg J, Billi S, Wolfson ML \& Franchi AM 2009 Endocannabinoid system and nitric oxide are involved in the deleterious effects of lipopolysaccharide on murine decidua. Placenta 30 579-584. (doi:10.1016/j.placenta.2009.04.003)

Vercelli CA, Aisemberg J, Cella M, Salazar AI, Wolfson ML \& Franchi AM 2012 Opposite effects of methanandamide on lipopolysaccharideinduced prostaglandin E2 and F2 $\alpha$ synthesis in uterine explants from pregnant mice. PLOS ONE 7 e39532. (doi:10.1371/journal. pone.0039532)

Wang H \& Dey SK 2005 Lipid signaling in embryo implantation. Prostaglandins \& Other Lipid Mediators 77 84-102. (doi:10.1016/ j.prostaglandins.2004.09.013)

Wang H, Matsumoto H, Guo Y, Paria BC, Roberts RL \& Dey SK 2003 Differential G protein-coupled cannabinoid receptor signaling by anandamide directs blastocyst activation for implantation. PNAS $\mathbf{1 0 0}$ 14914-14919. (doi:10.1073/pnas.2436379100)

Wang H, Guo Y, Wang D, Kingsley PJ, Marnett LJ, Das SK, DuBois RN \& Dey SK 2004 Aberrant cannabinoid signaling impairs oviductal transport of embryos. Nature Medicine 10 1074-1080. (doi:10.1038/nm1104)

Wang H, Dey SK \& Maccarrone M 2006a Jekyll and hyde: two faces of cannabinoid signaling in male and female fertility. Endocrine Reviews 27 427-448. (doi:10.1210/er.2006-0006)

Wang H, Xie H, Guo Y, Zhang H, Takahashi T, Kingsley PJ, Marnett LJ, Das SK, Cravatt BF \& Dey SK 2006b Fatty acid amide hydrolase deficiency limits early pregnancy events. Journal of Clinical Investigation 116 2122-2131. (doi:10.1172/JCl28621)

Wang H, Xie H, Sun X, Kingsley PJ, Marnett LJ, Cravatt BF \& Dey SK 2007 Differential regulation of endocannabinoid synthesis and degradation in the uterus during embryo implantation. Prostaglandins \& Other Lipid Mediators 83 62-74. (doi:10.1016/j.prostaglandins.2006.09.009)

Weber A, Ni J, Ling K-HJ, Acheampong A, Tang-Liu DD-S, Burk R, Cravatt BF \& Woodward D 2004 Formation of prostamides from anandamide in FAAH knockout mice analyzed by HPLC with tandem mass spectrometry. Journal of Lipid Research 45 757-763. (doi:10.1194/ jlr.M300475-JLR200)

Wenger T, Tóth BE \& Martin BR 1995 Effects of anandamide (endogen cannabinoid) on anterior pituitary hormone secretion in adult ovariectomized rats. Life Sciences 56 2057-2063. (doi:10.1016/00243205(95)00189-D)

Whan LB, West MCL, McClure N \& Lewis SEM 2006 Effects of delta9-tetrahydrocannabinol, the primary psychoactive cannabinoid in marijuana, on human sperm function in vitro. Fertility and Sterility $\mathbf{8 5}$ 653-660. (doi:10.1016/j.fertnstert.2005.08.027)

Wolfson ML, Aisemberg J, Salazar AI, Domínguez Rubio AP, Vercelli CA \& Franchi AM 2013 Progesterone reverts LPS-reduced FAAH activity in murine peripheral blood mononuclear cells by a receptormediated fashion. Molecular and Cellular Endocrinology 381 97-105. (doi:10.1016/j.mce.2013.07.020)

Wolfson ML, Correa F, Leishman E, Vercelli C, Cymeryng C, Blanco J, Bradshaw HB \& Franchi AM 2015 Lipopolysaccharide-induced murine embryonic resorption involves changes in endocannabinoid profiling and alters progesterone secretion and inflammatory response by a CB1-mediated fashion. Molecular and Cellular Endocrinology $\mathbf{4 1 1}$ 214-222. (doi:10.1016/j.mce.2015.04.032)

Xie H, Sun X, Piao Y, Jegga AG, Handwerger S, Ko MSH \& Dey SK 2012 Silencing or amplification of endocannabinoid signaling in blastocysts via CB1 compromises trophoblast cell migration. Journal of Biological Chemistry 287 32288-32297. (doi:10.1074/jbc.M112.381145)

Yu M, Ives D \& Ramesha CS 1997 Synthesis of prostaglandin E2 ethanolamide from anandamide by cyclooxygenase-2. Journal of Biological Chemistry 272 21181-21186. (doi:10.1074/jbc.272.34.21181)

Zoratti C, Kipmen-Korgun D, Osibow K, Malli R \& Graier WF 2003 Anandamide initiates $\mathrm{Ca}(2+)$ signaling via $\mathrm{CB} 2$ receptor linked to phospholipase $\mathrm{C}$ in calf pulmonary endothelial cells. British Journal of Pharmacology 140 1351-1362. (doi:10.1038/sj.bjp.0705529)

Received 29 March 2016

First decision 9 May 2016

Revised manuscript received 19 July 2016

Accepted 4 August 2016 